\title{
Efficacy and safety of intravenous golimumab plus methotrexate in patients with rheumatoid arthritis aged $<65$ years and those $\geq 65$ years of age
}

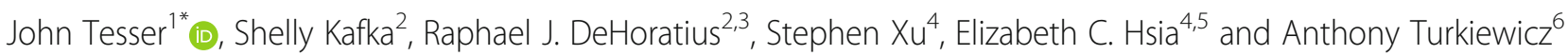

\begin{abstract}
Objective: To evaluate the safety and efficacy of intravenous golimumab + methotrexate (MTX) in patients with active rheumatoid arthritis (RA) aged $<65$ years and those $\geq 65$ years who were enrolled in the GO-FURTHER study.

Methods: In the phase III, double-blind, randomized, placebo-controlled GO-FURTHER trial, patients with active RA were randomized to intravenous (IV) golimumab $2 \mathrm{mg} / \mathrm{kg}+$ MTX or placebo + MTX at weeks 0 and 4, then every 8 weeks thereafter (with crossover to golimumab at week 16 [early escape] or week 24 [per-protocol]). The final golimumab infusion was at week 100. Assessments included American College of Rheumatology (ACR) 20/50/70 response criteria. Efficacy and adverse events (AEs) were monitored through 2 years. Efficacy and AEs were summarized for patients aged $<65$ years or $\geq 65$ years; AEs were also summarized for patients $<$ or $\geq$ 70 years and patients $<$ or $\geq 75$ years.
\end{abstract}

Results: In GO-FURTHER, 592 patients were randomized to receive placebo $(n=197)$ or golimumab $(n=395), 515$ were aged $<65$ years and 77 were $\geq 65$ years. At week 24, ACR20 response rates were greater for golimumab + MTX patients compared with placebo + MTX for patients $<65$ years (61.6\% vs 31.3\%, $p<0.001)$ and those $\geq 65$ years $(69.5 \%$ vs 33.3\%; $p<0.01)$. Infections were the most common AE through week $112(51.6 \%$ in patients < 65 years; $55.3 \%$ in patients $\geq 65$ years); upper respiratory infections were the most common infection in patients $<65$ years (13.2\%) and those $\geq 65$ years (11.8\%). Serious AEs occurred in $17.7 \%$ in patients $<65$ years and $25.0 \%$ of patients $\geq 65$ years and included malignancies, pneumonia, fractures, acute pancreatitis, cellulitis, and bacterial arthritis.

Conclusions: In GO-FURTHER, ACR response rates were similar between patients $<65$ years and patients $\geq 65$ years within each treatment group. AEs in elderly patients were similar to the known safety profile of IV golimumab. Immunosenescence is known to increase the risk of infections in the elderly. Elderly patients had a numerically higher incidence of serious infections. Six malignancies occurred in golimumab-treated patients, all in patients $<65$ years.

Trial registration: clinicaltrials.gov: NCT00973479. Registered September 9, 2009.

Keywords: Rheumatoid arthritis, Geriatric, Anti-tumor necrosis factor, Golimumab

\footnotetext{
* Correspondence: jtesser1@cox.net

'Arizona Arthritis and Rheumatology Associates, Phoenix, AZ, USA

Full list of author information is available at the end of the article
}

(c) The Author(s). 2019 Open Access This article is distributed under the terms of the Creative Commons Attribution 4.0 International License (http://creativecommons.org/licenses/by/4.0/), which permits unrestricted use, distribution, and reproduction in any medium, provided you give appropriate credit to the original author(s) and the source, provide a link to the Creative Commons license, and indicate if changes were made. The Creative Commons Public Domain Dedication waiver (http://creativecommons.org/publicdomain/zero/1.0/) applies to the data made available in this article, unless otherwise stated. 


\section{Background}

Biologics targeting tumor necrosis factor (TNF) are an effective therapy for reducing the inflammation and improving the signs and symptoms of rheumatoid arthritis (RA). Golimumab is a fully human monoclonal antiTNF antibody and is available as a subcutaneous (SC) injection or an intravenous (IV) infusion. The safety profile of golimumab has been established from trials of SC golimumab in patients with RA [1-3], psoriatic arthritis (PsA) [4], ankylosing spondylitis (AS) [5], and ulcerative colitis [6] and from trials of IV golimumab in patients with RA [7], PsA [8], and AS [9]. The adverse events (AEs) reported in these trials have been consistent with those reported for other anti-TNF therapies. Overall, patients with RA who are treated with antiTNF therapies are at an increased risk for infections and serious infections, including opportunistic infections, and screening for tuberculosis is recommended as described in the prescribing information [10-14]. In addition, other AEs of interest include malignancies and cardiovascular events.

In clinical trials and post-marketing experience in patients with RA, the proportions of patients who had a serious $\mathrm{AE}$ while receiving golimumab $\mathrm{SC}$ or IV have been low. However, there is a paucity of data of the safety of golimumab, and anti-TNF agents in general, among patients aged 65 years and older. In one study of patients with RA who were 65 years and older, there was no increase in the incidence of serious bacterial infections for patients receiving anti-TNF therapy when compared with patients treated with methotrexate (MTX) only; however, the use of glucocorticoids was associated with an increased risk [15]. In a retrospective analysis of patients with RA enrolled in a Korean registry, the rates of infections and malignancies were higher in patients 65 years and older than in patients who were younger, although these differences were not statistically significant [16]. In another analysis of data from four randomized trials of patients with RA treated with etanercept, the rates of serious adverse events (SAEs) and serious infections were higher in older patients compared with younger patients in three of the studies, although no difference was seen in the fourth study [17]. In the same analysis, the rate of malignancies among elderly patients was higher than for younger patients, but was consistent with the same age group in the general population [17].

In the phase 3 GO-FURTHER study, the safety and efficacy of IV golimumab $2 \mathrm{mg} / \mathrm{kg}$ was evaluated in adults with active RA despite treatment with MTX [18]. Safety events that occurred during GO-FURTHER were consistent with those previously reported with $\mathrm{SC}$ golimumab in patients with RA [1-3], PsA [4], and AS [5]. We performed an exploratory analysis to compare the safety and efficacy following golimumab plus MTX therapy in patients aged 65 years and older who were enrolled in the GO-FURTHER study.

\section{Methods}

\section{Patients and study design}

The details of the GO-FURTHER patient population and study design have been previously published [18]. The GO-FURTHER trial was a phase 3, randomized, placebocontrolled trial. Adults with active RA ( $\geq 6$ swollen and $\geq 6$ tender joints) for $\geq 3$ months despite MTX therapy were eligible for enrollment. Patients also had to have a screening C-reactive protein level $\geq 1.0 \mathrm{mg} / \mathrm{dL}$ and a positive status for either anti-cyclic citrullinated peptide antibodies or rheumatoid factor. Patients who were receiving MTX had to have been receiving a stable dose ( $\geq 15 \mathrm{mg} /$ week) for $\geq 3$ months at screening and a stable dose (15-25 mg/week) for $\geq 4$ weeks prior to enrollment. Concomitant use of oral corticosteroids ( $\leq 10 \mathrm{mg}$ / day of prednisone or equivalent) and nonsteroidal antiinflammatory drugs (NSAIDs) (or other analgesics for RA, at usual approved doses) was permitted at stable doses [18]. Prior biologic therapy was not permitted, but patients could have received prior treatment with disease-modifying anti-rheumatic drugs (DMARDs) (other than MTX) and systemic immunosuppressives (e.g., Dpenicillamine, hydroxychloroquine, chloroquine, oral or parenteral gold, sulfasalazine, leflunomide, azathioprine, cyclosporine, mycophenolate mofetil), but these medications were not permitted within 4 weeks of the first study drug administration.

Patients could not have a history of latent or active tuberculosis (TB) prior to screening and were screened using the QuantiFERON-TB Gold test or tuberculin skin test (if the former was not approved in that country) within 6 months before the first study agent administration and chest radiograph within 3 months before the first study agent administration. In addition, patients were excluded if they had received, or were expected to receive, any live virus or bacterial vaccination within 3 months prior to the first administration of study agent, during the study, or within 6 months after the last administration of study agent.

Eligible patients were randomized $(2: 1)$ to receive IV infusions of golimumab $2 \mathrm{mg} / \mathrm{kg}$ at weeks 0,4 , and every 8 weeks thereafter or placebo at weeks 0,4 , and 12 , with crossover to golimumab $2 \mathrm{mg} / \mathrm{kg}$ at weeks 24,28 , and every 8 weeks thereafter through week 100 . Patients in the placebo plus MTX group with $<10 \%$ improvement in swollen and tender joint counts from baseline to week 16 entered early escape and received golimumab at weeks 16, 20, and every 8 weeks. All patients continued to receive a stable dose of MTX (15-25 mg/week). 


\section{Statistical methods}

This analysis included only patients who received $\geq 1$ IV golimumab administration, and patients were grouped according to age: $<65$ years or $\geq 65$ years, $<70$ years or $\geq 70$ years, and $<75$ years or $\geq 75$ years. Efficacy was determined using the American College of Rheumatology (ACR) criteria. The proportion of patients who achieved $\geq 20 \%, 50 \%$, or $70 \%$ improvement in the ACR criteria (ACR20/ACR50/ACR70 response) was determined for patients $<65$ years or $\geq 65$ years; nominal $p$ values (chi-square test) were generated for comparisons between treatment groups in each age group separately without adjustment for multiplicity. Nonresponder imputation was used for patients who met the treatment failure or early escape criteria. For patients with missing data, last observation carried forward was used for ACR components. Physical function was evaluated using the Health Assessment Questionnaire-Disability Index (HAQ-DI) [19] and general health-related quality of life (HRQoL) and 36-item Short-Form Health Survey Physical and Mental Component Summary (SF-36 PCS/ MCS) scores [20]. ACR response and change in HAQDI were determined for weeks 14, 24, 52, and 100; change in SF-36 PCS and MCS scores was determined for weeks 12, 24, 52, and 112. Efficacy analyses were not performed for the higher age cutoffs (70 year and 75 years) due to the small numbers of patients in these groups. Safety events through 2 years were summarized for patients $<65$ years or $\geq 65$ years, patients $<70$ years or $\geq 70$ years, and patients $<75$ or $\geq 75$ years.

\section{Results}

\section{Baseline demographic and disease characteristics}

The GO-FURTHER study was conducted at 92 sites in 13 countries (Argentina, Australia, Columbia, Hungary, Korea, Lithuania, Malaysia, Mexico, New Zealand, Poland, Russia, Ukraine, and the USA). Patients were randomized to receive placebo plus MTX $(n=197)$ or golimumab plus MTX $(n=395)$ at baseline. Demographic and disease characteristics were well-balanced between the treatment groups [18]. In this analysis, there were 515 patients aged $<65$ years and 77 patients $\geq 65$ years. Baseline demographics and disease characteristics for these patients are reported in Table 1. As expected, the mean ages differed between patients $<65$ years and those $\geq 65$ years. The proportions of patients receiving oral corticosteroids, NSAIDs, and DMARDs were lower among those aged $\geq 65$ years. Patients $\geq 65$ years had a longer mean RA disease duration and a slightly lower mean dose of oral corticosteroids at baseline compared with patients $<65$ years. MTX use was categorized by time periods of ( $<1$ year, 1 to $<3$ years, $\geq 3$ years), and a greater proportion of younger patients seemed to be receiving MTX for longer than 3 years compared with patients $\geq 65$ years. Other demographic and disease characteristics, including the ACR core assessments, were similar between these patient age groups.

\section{Efficacy}

At weeks 14 and 24, greater proportions of golimumabtreated patients achieved an ACR20 and ACR50 response compared with placebo among patients aged $<65$ years and those $\geq 65$ years. In addition, greater proportions of golimumab-treated patients achieved an ACR70 response compared with placebo in both age groups; however, the difference between treatment groups did not reach statistical significance among patients $\geq 65$ years (Fig. 1). At weeks 52 and 100, when all patients had been receiving golimumab plus MTX since week 24, the proportions of patients achieving ACR20, ACR50, and ACR70 responses were similar for patients $<65$ years and those $\geq 65$ years within each treatment group (Fig. 1).

Mean improvements in HAQ-DI scores were also greater in the golimumab group compared with placebo in patients $<65$ years and patients $\geq 65$ years at weeks 14 and 24 (Table 2). Mean improvements in SF-36 PCS and MCS scores were greater in the golimumab-treated patients compared with placebo at weeks 12 and 24; however, differences between the treatment groups did not always reach significance among patients $\geq 65$ years (Table 2). Among patients $<65$ years, mean improvements in HAQ-DI and SF-36 PCS and MCS scores were sustained in the golimumab group through weeks 52 and 100/112, and improvements in the placebo crossover group approached those of the golimumab group at weeks 52 and 100/112. Among patients $\geq 65$ years, improvements in HAQ-DI and SF-36 PCS and MCS scores were maintained through week 100/112 in the golimumab group. Patients who crossed over from placebo to golimumab also demonstrated improvements at weeks 52 and 100/112, although these improvements were smaller than those in the golimumab group; however, the small number of patients $\geq 65$ years in the placebo crossover group limits the interpretation of these results.

\section{Safety}

Through week 24, nine patients $(2.2 \%)$ in the golimumab plus MTX group discontinued study treatment due to an AE. Of these, six patients $(1.8 \%)$ were $<65$ years at baseline, and three $(5.1 \%)$ were $\geq 65$ years of age. Through week 52 in the golimumab plus MTX group, 11 patients $(3.3 \%)<65$ years and four patients $(6.8 \%) \geq 65$ years discontinued study treatment due to AEs; through week 112, 23 patients $(6.8 \%)<65$ years and 9 patients $(15.3 \%) \geq 65$ years discontinued study treatment due to AEs. Overall, 86 (16.7\%) patients < 65 years and 20 (26.0\%) patients $\geq 65$ years discontinued study agent through week 112. The two most common reasons 
Table 1 Baseline demographic and disease characteristics for patients $<65$ years and $\geq 65$ years

\begin{tabular}{|c|c|c|c|c|c|c|}
\hline & \multicolumn{3}{|c|}{ Patients < 65 years } & \multicolumn{3}{|c|}{ Patients $\geq 65$ years } \\
\hline & $\begin{array}{l}\text { Placebo + } \\
\text { MTX }\end{array}$ & $\begin{array}{l}\text { Golimumab + } \\
\text { MTX }\end{array}$ & Combined & $\begin{array}{l}\text { Placebo + } \\
\text { MTX }\end{array}$ & $\begin{array}{l}\text { Golimumab + } \\
\text { MTX }\end{array}$ & Combined \\
\hline Patients, $n$ & 179 & 336 & 515 & 18 & 59 & 77 \\
\hline Age, years & $49.5 \pm 9.9$ & $48.7 \pm 10.7$ & $49.0 \pm 10.4$ & $70.4 \pm 3.4$ & $70.1 \pm 4.3$ & $70.2 \pm 4.1$ \\
\hline Female & $141(78.8)$ & $276(82.1)$ & $417(81.0)$ & $16(88.9)$ & $50(84.7)$ & $66(85.7)$ \\
\hline \multicolumn{7}{|l|}{ Race } \\
\hline Caucasian & $145(81.0)$ & $272(81.2)$ & $417(81.1)$ & $15(83.3)$ & $43(72.9)$ & $58(75.3)$ \\
\hline Asian & $10(5.6)$ & $30(9.0)$ & $40(7.8)$ & $2(11.1)$ & $1(1.7)$ & $3(3.9)$ \\
\hline Black & $0(0.0)$ & $0(0.0)$ & $0(0.0)$ & $0(0.0)$ & $1(1.7)$ & $1(1.3)$ \\
\hline Other & $24(13.4)$ & $33(9.8)$ & $57(11.1)$ & $1(5.6)$ & $14(23.7)$ & $15(19.5)$ \\
\hline Weight, kg & $71.7 \pm 17.4$ & $72.4 \pm 16.2$ & $72.2 \pm 16.6$ & $73.8 \pm 15.3$ & $66.3 \pm 14.3$ & $68.1 \pm 14.7$ \\
\hline $\mathrm{BMI}, \mathrm{kg} / \mathrm{m}^{2}$ & $26.9 \pm 5.7$ & $27.0 \pm 5.6$ & $27.0 \pm 5.6$ & $28.3 \pm 5.5$ & $25.8 \pm 4.9$ & $26.4 \pm 5.1$ \\
\hline RA disease duration & $6.6 \pm 6.3$ & $6.5 \pm 6.3$ & $6.5 \pm 6.3$ & $10.8 \pm 13.1$ & $9.3 \pm 9.8$ & $9.7 \pm 10.6$ \\
\hline \multicolumn{7}{|l|}{ ACR core components } \\
\hline Number of swollen joints (0-68) & $14.7 \pm 8.4$ & $15.0 \pm 8.5$ & $14.9 \pm 8.5$ & $15.9 \pm 9.8$ & $14.6 \pm 6.2$ & $14.9 \pm 7.2$ \\
\hline Numbers of tender joints (0-68) & $25.9 \pm 14.3$ & $26.6 \pm 13.7$ & $26.3 \pm 13.9$ & $25.8 \pm 12.8$ & $25.5 \pm 15.2$ & $25.6 \pm 14.6$ \\
\hline $\mathrm{CRP}, \mathrm{mg} / \mathrm{dL}$ & $2.3 \pm 1.9$ & $2.8 \pm 2.7$ & $2.6 \pm 2.5$ & $1.5 \pm 1.1$ & $3.1 \pm 3.7$ & $2.7 \pm 3.4$ \\
\hline $\begin{array}{l}\text { Physician's global assessment (VAS, 0-10 } \\
\mathrm{cm} \text { ) }\end{array}$ & $6.3 \pm 1.5$ & $6.3 \pm 1.6$ & $6.3 \pm 1.6$ & $5.9 \pm 2.0$ & $6.0 \pm 1.7$ & $5.9 \pm 1.7$ \\
\hline Patient's global assessment (VAS, $0-10 \mathrm{~cm}$ ) & $6.5 \pm 1.9$ & $6.5 \pm 1.8$ & $6.5 \pm 1.9$ & $6.2 \pm 2.2$ & $6.3 \pm 1.8$ & $6.3 \pm 1.9$ \\
\hline Patient's assessment of pain (VAS, $0-10 \mathrm{~cm})$ & $6.5 \pm 2.0$ & $6.5 \pm 1.9$ & $6.5 \pm 1.9$ & $6.6 \pm 2.0$ & $6.5 \pm 1.6$ & $6.5 \pm 1.7$ \\
\hline HAQ-DI & $1.60 \pm 0.60$ & $1.55 \pm 0.66$ & $1.56 \pm 0.64$ & $1.35 \pm 0.72$ & $1.61 \pm 0.71$ & $1.55 \pm 0.72$ \\
\hline Anti-CCP antibodies & 165/177 (93.2) & $307 / 335(91.6)$ & $\begin{array}{l}472 / 512 \\
(92.2)\end{array}$ & $16(88.9)$ & $55(93.2)$ & $71(92.2)$ \\
\hline Rheumatoid factor & $164(91.6)$ & $309(92.0)$ & $473(91.8)$ & $17(94.4)$ & $56(94.9)$ & $73(94.8)$ \\
\hline SF-36 PCS & $30.8 \pm 7.2$ & $31.0 \pm 6.6$ & $30.9 \pm 6.8$ & $31.7 \pm 8.9$ & $30.0 \pm 7.8$ & $30.4 \pm 8.0$ \\
\hline SF-36 MCS & $38.3 \pm 11.7$ & $36.8 \pm 11.1$ & $37.3 \pm 11.3$ & $41.0 \pm 10.4$ & $38.9 \pm 11.1$ & $39.4 \pm 10.9$ \\
\hline \multicolumn{7}{|l|}{ Concomitant medications } \\
\hline MTX dose at screening & $16.7 \pm 2.8$ & $16.9 \pm 2.9$ & $16.8 \pm 2.9$ & $16.4 \pm 2.9$ & $16.3 \pm 2.8$ & $16.3 \pm 2.8$ \\
\hline \multicolumn{7}{|l|}{ Duration of MTX use } \\
\hline$<1$ year & $44(24.6)$ & $82(24.4)$ & $126(24.5)$ & $4(22.2)$ & $20(33.9)$ & $24(31.2)$ \\
\hline 1 to $<3$ years & $53(29.6)$ & $97(28.9)$ & $150(29.1)$ & $8(44.4)$ & $17(28.8)$ & $25(32.5)$ \\
\hline$\geq 3$ years & $82(45.8)$ & $154(45.8)$ & $236(45.8)$ & $6(33.3)$ & $22(37.3)$ & $28(36.4)$ \\
\hline Unknown & $0(0.0)$ & $3(0.9)$ & $3(0.6)$ & $0(0.0)$ & $0(0.0)$ & $0(0.0)$ \\
\hline Oral corticosteroids & $121(67.6)$ & $221(65.8)$ & $342(66.4)$ & $13(72.2)$ & $30(50.8)$ & $43(55.8)$ \\
\hline Dose (prednisone or equivalent), mg/day & $7.0 \pm 2.5$ & $7.1 \pm 2.5$ & $7.0 \pm 2.5$ & $6.9 \pm 2.7$ & $6.6 \pm 2.7$ & $6.7 \pm 2.6$ \\
\hline NSAIDs & $145(81.0)$ & $280(83.3)$ & $425(82.5)$ & $11(61.1)$ & $43(72.9)$ & $54(70.1)$ \\
\hline \multicolumn{7}{|l|}{ Prior medications } \\
\hline DMARDs* & $83(46.4)$ & $182(54.2)$ & $265(51.5)$ & $9(50.0)$ & $24(40.7)$ & $33(42.9)$ \\
\hline
\end{tabular}

Data presented as $n(\%)$ or mean \pm standard deviation, unless otherwise noted

$A C R$ American College of Rheumatology, BMI body mass index, CCP cyclic citrullinated peptide, CRP C-reactive protein, DMARDs disease-modifying anti-rheumatic drugs, HAQ-DI health assessment questionnaire-disability index, MTX methotrexate, NSAIDs nonsteroidal anti-inflammatory drugs, RA rheumatoid arthritis, SF-36 PCS/MCS 36-item Short Form Health Survey Physical/Mental Component Summary, VAS visual analog scale *DMARDs other than MTX were discontinued $\geq 4$ weeks prior to the first study agent administration

for discontinuation were AEs $(n=44 ; 6.2 \%$ of patients $<65$ years, $15.6 \%$ of patients $\geq 65$ years) and withdrawal of consent $(n=31 ; 5.2 \%$ of patients $<65$ years, $5.2 \%$ of patients $\geq 65$ years). Among patients $<70$ years, $6.5 \%$ discontinued study agent due to an $\mathrm{AE}$, and $5.4 \%$ withdrew consent; among patients $\geq 70$ years, $21.1 \%$ discontinued 

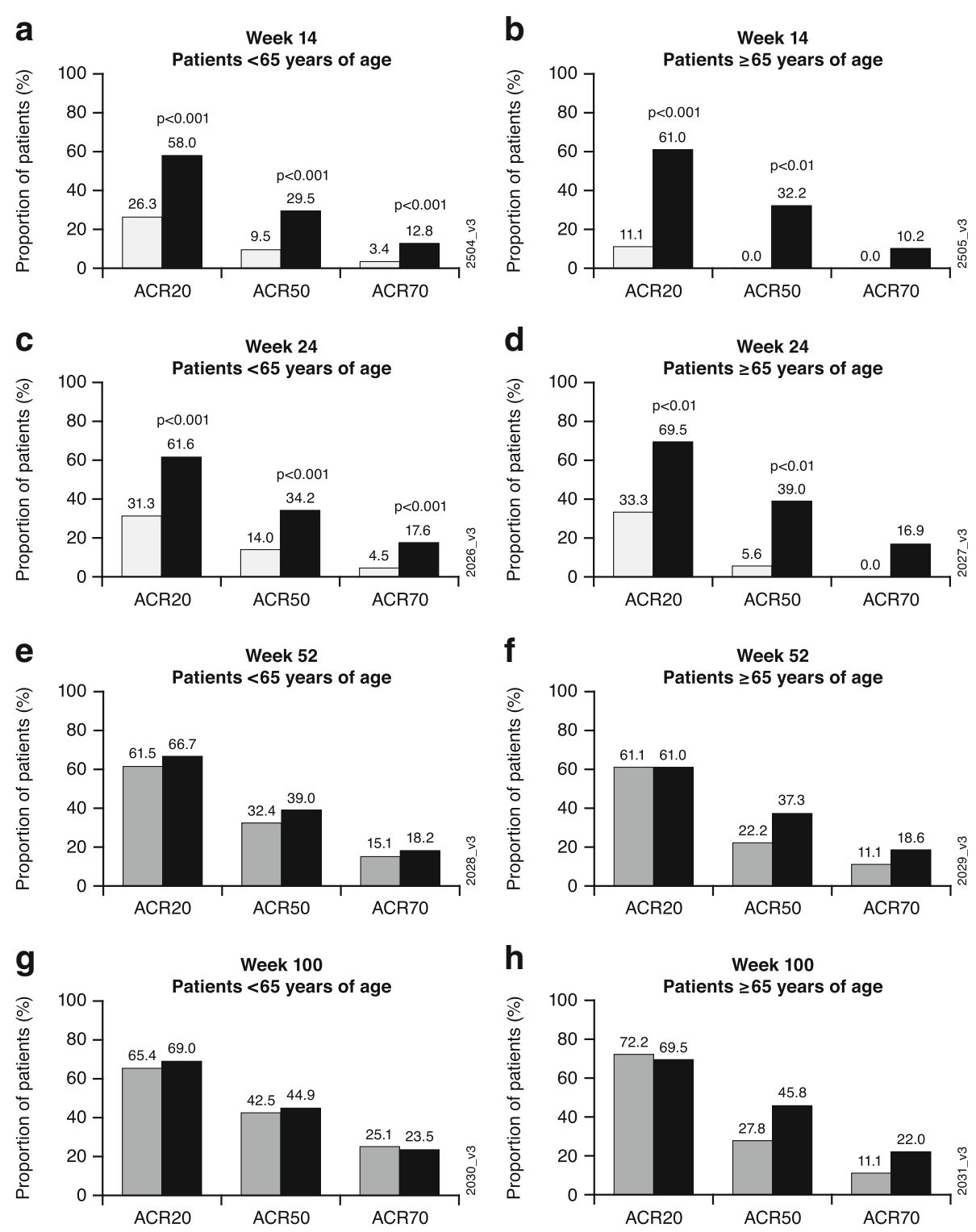

$$
\text { Placebo + MTX } \square \text { Placebo + MTX } \rightarrow \text { Golimumab } 2 \mathrm{mg} / \mathrm{kg}+\text { MTX }
$$

Golimumab $2 \mathrm{mg} / \mathrm{kg}+\mathrm{MTX}$

Fig. 1 Proportions of patients $<65$ years and $\geq 65$ years achieving ACR20, ACR50, and ACR70 responses at weeks 14 (a, b), 24 (c, d), 52 (e, f), and $100(\mathbf{g}, \mathbf{h})$. Patients in the placebo group could receive golimumab at week 16 if they met the early escape criteria; all other patients in the placebo group crossed over to golimumab at week 24. Treatment group comparisons were not performed after week 24. ACR20/50/70 $\geq 20 \% /$ 50\%/70\% improvement in American College of Rheumatology criteria

due to an $\mathrm{AE}, 2.6 \%$ withdrew consent, and $2.6 \%$ discontinued due to lack of efficacy. Among patients $<75$ years, 6.9\% discontinued study agent due to an $\mathrm{AE}$, and 5.3\% withdrew consent; among patients $\geq 75$ years, $40.0 \%$ discontinued due to an $\mathrm{AE}$, and all other discontinuations were for reasons other than AEs, withdrawal of consent or lack of efficacy.

Infections were the most common type of $\mathrm{AE}$ through week 52. The incidence of infections was similar between patients $<65$ years $(214 / 508,42.1 \%)$ and those $\geq$
65 years $(30 / 76,39.5 \%)$ and between patients $<70$ years $(227 / 547,41.5 \%)$ and $\geq 70$ years $(17 / 37,45.9 \%)$. Patients $\geq 75$ years had a higher incidence of infections through week 52 than did patients $<75$ years $(5 / 10,50.0 \%$, and $239 / 574,41.6 \%$, respectively); however, the number of patients $\geq 75$ years was small. Similar results were observed for the incidence of infections through week 112 (Table 3). Through week 112, upper respiratory infections were the most common infection in patients $<65$ years $(n=67 / 508 ; 13.2 \%)$ and those $\geq 65$ years $(n=9 / 76$; 
Table 2 Physical function and health-related quality of life through week 100/112

\begin{tabular}{|c|c|c|c|c|}
\hline & \multicolumn{2}{|l|}{ Patients $<65$ years } & \multicolumn{2}{|l|}{ Patients $\geq 65$ years } \\
\hline & $\begin{array}{l}\text { Placebo + MTX } \rightarrow \text { Golimumab + MTX } \\
(n=179)\end{array}$ & $\begin{array}{l}\text { Golimumab + MTX } \\
(n=336)\end{array}$ & $\begin{array}{l}\text { Placebo + MTX } \\
\rightarrow \text { Golimumab + MTX } \\
(n=18)\end{array}$ & $\begin{array}{l}\text { Golimumab + MTX } \\
(n=59)\end{array}$ \\
\hline \multicolumn{5}{|c|}{ Improvement from baseline in HAQ-DI } \\
\hline Week 14 & $0.20 \pm 0.57$ & $0.50 \pm 0.56^{* * *}$ & $0.10 \pm 0.35$ & $0.50 \pm 0.65^{*}$ \\
\hline Week 24 & $0.22 \pm 0.56$ & $0.53 \pm 0.62^{* * *}$ & $0.07 \pm 0.43$ & $0.53 \pm 0.71^{* *}$ \\
\hline Week 52 & $0.45 \pm 0.60$ & $0.53 \pm 0.65$ & $0.11 \pm 0.41$ & $0.40 \pm 0.63$ \\
\hline Week 100 & $0.49 \pm 0.63$ & $0.55 \pm 0.67$ & $0.29 \pm 0.56$ & $0.44 \pm 0.60$ \\
\hline \multicolumn{5}{|c|}{ Mean change from baseline in SF-36 PCS } \\
\hline Week 12 & $3.3 \pm 7.4$ & $5.9 \pm 7.5^{* * *}$ & $2.1 \pm 7.3$ & $6.0 \pm 8.7$ \\
\hline Week 24 & $4.0 \pm 7.2$ & $8.2 \pm 8.2^{* * *}$ & $2.3 \pm 8.6$ & $8.9 \pm 8.9^{* *}$ \\
\hline Week 52 & $7.1 \pm 8.0$ & $8.2 \pm 8.8$ & $4.4 \pm 8.7$ & $7.4 \pm 8.9$ \\
\hline Week 112 & $7.2 \pm 8.7$ & $7.7 \pm 9.0$ & $5.7 \pm 6.3$ & $6.8 \pm 10.1$ \\
\hline \multicolumn{5}{|c|}{ Mean change from baseline in SF-36 MCS } \\
\hline Week 12 & $1.6 \pm 10.2$ & $5.3 \pm 10.0^{* * *}$ & $0.02 \pm 5.80$ & $2.9 \pm 11.5$ \\
\hline Week 24 & $1.2 \pm 10.3$ & $7.1 \pm 10.2^{* * *}$ & $1.7 \pm 7.6$ & $6.0 \pm 10.7$ \\
\hline Week 52 & $4.1 \pm 11.4$ & $7.1 \pm 11.0$ & $2.0 \pm 9.2$ & $5.8 \pm 12.2$ \\
\hline Week 112 & $3.9 \pm 11.5$ & $6.0 \pm 11.3$ & $1.7 \pm 9.2$ & $4.4 \pm 10.7$ \\
\hline
\end{tabular}

All data are presented as mean \pm standard deviation

HAQ-DI health assessment questionnaire-disability index, MTX methotrexate, SF-36 PCS/MCS 36-item Short Form Health Survey Physical/Mental Component Summary

${ }^{*} p<0.05,{ }^{* *} p<0.01,{ }^{* * *} p<0.001$

$11.8 \%)$. The incidence of cellulitis was slightly higher among patients $\geq 65$ years $(n=4 / 76,5.3 \%)$ compared with those $<65$ years $(n=10 / 508,2.0 \%)$. Among patients $\geq 65$ years, other infections included fungal urinary tract infection $(n=1)$ and septic arthritis $(n=2)$. There were four cases of herpes zoster; three occurred in patients $<65$ years and one in a patient $\geq 70$ years, and none were classified as serious or severe. Among patients who received golimumab plus MTX, 16/508 (3.1\%) patients $<65$ years and $7 / 76(9.2 \%) \geq 65$ years

Table 3 Adverse events through week 52 and week 112 for patients who received at least one administration of golimumab

\begin{tabular}{|c|c|c|c|c|c|c|}
\hline & $\begin{array}{l}\text { Patients } \\
<65 \text { years }\end{array}$ & $\begin{array}{l}\text { Patients } \\
\geq 65 \text { years }\end{array}$ & $\begin{array}{l}\text { Patients } \\
<70 \text { years }\end{array}$ & $\begin{array}{l}\text { Patients } \\
\geq 70 \text { years }\end{array}$ & $\begin{array}{l}\text { Patients } \\
<75 \text { years }\end{array}$ & $\begin{array}{l}\text { Patients } \\
\geq 75 \text { years }\end{array}$ \\
\hline Patients, $n$ & 508 & 76 & 547 & 37 & 574 & 10 \\
\hline \multicolumn{7}{|l|}{ Through week 52} \\
\hline Mean duration of follow-up, weeks & 43.5 & 43.2 & 43.6 & 41.8 & 43.5 & 40.5 \\
\hline Mean number of golimumab infusions & 5.9 & 5.8 & 5.9 & 5.6 & 5.9 & 5.4 \\
\hline Patients with $\geq 1 \mathrm{AE}$ & $355(69.9)$ & $52(68.4)$ & $379(69.3)$ & $28(75.7)$ & $397(69.2)$ & $10(100.0)$ \\
\hline Patients with infections & $214(42.1)$ & $30(39.5)$ & $227(41.5)$ & $17(45.9)$ & $239(41.6)$ & $5(50.0)$ \\
\hline Patients with $\geq 1$ SAE & $45(8.9)$ & $9(11.8)$ & $49(9.0)$ & $5(13.5)$ & $50(8.7)$ & $4(40.0)$ \\
\hline Patients with serious infections & $7(1.4)$ & $4(5.3)$ & $10(1.8)$ & $1(2.7)$ & $10(1.7)$ & $1(10.0)$ \\
\hline \multicolumn{7}{|l|}{ Through week 112} \\
\hline Mean duration of follow-up, weeks & 96.6 & 90.9 & 96.4 & 88.7 & 96.2 & 76.9 \\
\hline Mean number of golimumab infusions & 12.0 & 11.3 & 12.0 & 10.9 & 12.0 & 9.4 \\
\hline Patients with $\geq 1 \mathrm{AE}$ & $417(82.1)$ & $61(80.3)$ & $445(81.4)$ & $33(89.2)$ & $468(81.5)$ & $10(100.0)$ \\
\hline Patients with infections & $262(51.6)$ & $42(55.3)$ & $279(51.0)$ & $25(67.6)$ & $297(51.7)$ & $7(70.0)$ \\
\hline Patients with $\geq 1 \mathrm{SAE}$ & $90(17.7)$ & $19(25.0)$ & $97(17.7)$ & $12(32.4)$ & $102(17.8)$ & $7(70.0)$ \\
\hline Patients with serious infections & $27(5.3)$ & $9(11.8)$ & $32(5.9)$ & $4(10.8)$ & $34(5.9)$ & $2(20.0)$ \\
\hline
\end{tabular}


had an infusion reaction through week 112. Skin reactions were the most common type of reaction among patients $<65$ years $(n=5)$; vascular disorders (hypertension and flushing) were the most common reaction among patients $\geq 65$ years $(n=3)$. Two patients in each age group experienced an infusion reaction of headache. None were considered serious or severe. No patient aged $\geq 65$ years discontinued golimumab therapy due to an infusion reaction; one golimumab-treated patient, aged 39 years, discontinued due to a nonserious infusion reaction (mild skin reaction).

The proportion of patients with at least one SAE through week 52 was numerically higher in patients $\geq 65$ years $(9 / 76,11.8 \%)$ than in those aged $<65$ years $(45 / 508,8.9 \%)$. Through week 52 , the proportion of patients with at least one SAE was numerically higher for patients $\geq 70$ years $(5 / 37,13.5 \%)$ compared with patients $<70$ years $(49 / 547,9.0 \%)$ and for patients $\geq 75$ years $(4 / 10,40.0 \%$; cholecystitis and electrolyte imbalance [both in one patient], hemorrhoids, cerebral infarction, interstitial lung disease) compared with patients $<75$ years $(50 / 574,8.7 \%)$. However, it should be noted that the numbers of patients $\geq 70$ years and $\geq 75$ years were relatively small. A similar trend was also observed for the proportions of patients with at least one $\mathrm{AE}$ through week 52.

Through week 112, 19 (25.0\%) patients $\geq 65$ years had an SAE, including cellulitis and bacterial arthritis. Among patients $\geq 75$ years $(n=10), 7(70.0 \%)$ had an SAE, including intervertebral discitis and diverticulosis. Ninety patients $(17.7 \%)<65$ years had an SAE through week 112, including one patient with acute pancreatitis. Other SAEs through week 112 included fractures in eight golimumab plus MTX-treated patients: five who were $<65$ years, one who was $\geq 65$ and $<70$ years (femoral neck fracture), one who was $\geq 70$ and $<75$ years (upper limb fracture), and one who was $\geq 75$ years (spinal compression fracture; same patient with the intervertebral discitis). Additionally, among patients treated with golimumab plus MTX, six malignancies were reported through week 112; all occurred in patients $<65$ years (breast cancer, cervical carcinoma stage 0 , basal cell carcinoma $(n=2)$, Bowen's disease, and chronic lymphocytic leukemia).

In the overall GO-FURTHER population, 36 golimumab plus MTX-treated patients (6.2\%) experienced a serious infection through week 112 [7]. In this post hoc analysis by age, there was a higher incidence of serious infections among patients $\geq 65$ years, $\geq 70$ years, and $\geq$ 75 years when compared with patients $<65$ years, $<70$ years, and $<75$ years, respectively, through weeks 52 and 112 ; however, the numbers of patients $\geq 70$ years and $\geq$ 75 years were small. Serious infections included sepsis $(n=2)$, septic arthritis $(n=1)$, and cellulitis $(n=1)$ among patients $\geq 65$ years and rectal abscess $(n=1)$, sepsis $(n=1)$, and urosepsis $(n=1)$ among patients $<65$ years. Two serious opportunistic infections were reported: infective spondylitis (Candida albicans) in a patient $\geq 75$ years and a serious infection of cryptococcal pneumonia in a patient $\geq 65$ years from South Korea. Three cases of active tuberculosis were reported through week 112, all in patients younger than 65 years. Through week 112, seven patients experienced an SAE of pneumonia; all were younger than 65 years, with the exception of the patient with cryptococcal pneumonia. There was no predominant type of serious infection, including opportunistic infections, among patients $\geq 65$ years. Among patients who did not use corticosteroids at baseline, the incidence of serious infections through week 112 was similar for patients $<65$ years and $\geq 65$ years $(13 / 170$, $7.6 \%$, and $3 / 33,9.1 \%$, respectively), while among patients who received oral corticosteroids at baseline, the incidence of serious infections was numerically higher for patients $\geq 65$ years $(6 / 43,14.0 \%)$ compared with those $<65$ years $(14 / 338,4.1 \%)$.

A total of five deaths occurred through 2 years in patients who received golimumab plus MTX [7, 18]: four occurred in patients who were younger than 65 years (myocardial infarction complicated by presumed pneumonia, abdominal tuberculosis, septic shock, and unknown causes) and one occurred in a patient older than 65 years (Clostridium difficile). One death occurred in a patient receiving placebo plus MTX $(<65$ years; presumed stroke secondary to hypertensive crisis) as previously reported [18].

\section{Discussion}

Maintenance of efficacy through 2 years of treatment with IV golimumab $2 \mathrm{mg} / \mathrm{kg}$ plus MTX in the GO-FURTHER trial of biologic-naïve patients with RA has been previously demonstrated $[7,18]$. In the current analysis, greater proportions of golimumab plus MTX-treated patients achieved an ACR20 response at weeks 14 and 24 compared with placebo plus MTX both in patients $<65$ years and those $\geq 65$ years. A similar treatment effect at week 24 was observed in both age groups. At weeks 52 and 100, ACR response rates remained similar for both age groups. Likewise, improvements in physical function and HRQoL were greater among golimumab-treated patients compared with placebo in both age groups through week 24 . Among patients $\geq 65$ years, those in the placebo group generally had smaller improvements in physical function and HRQoL even after crossing over to golimumab. Of note, the number of patients in this group was small $(n=18)$, mean age was 70 years, and these patients had a higher mean disease duration compared with patients $<65$ years, which may have affected these outcome measures. 
Through week 112, the proportions of golimumab plus MTX-treated patients with at least one AE were similar for patients $<65$ years and those $\geq 65$ years; similar results were observed when using the 70 years and 75 years age cutoffs. Infections were the most common type of AE, which is consistent with the known safety profile of golimumab. The proportions of patients with an SAE were numerically higher in the patients $\geq 65$ years, $\geq 70$ years, and $\geq 75$ years compared with those $<65$ years, $<70$ years, and $<75$ years, respectively. Similar trends were also seen for serious infections. Few patients experienced infusion reactions with golimumab (< 65 years: $16 / 508,3.1 \%$; $\geq 65$ years: $7 / 76,9.2 \%)$. None of the infusion reactions were considered serious or severe, and there were no discontinuations of study treatment due to an infusion reaction among patients $\geq 65$ years. However, these comparisons should be interpreted with caution due to the relatively small population sizes in the older age groups.

The use of anti-TNF therapy has been associated with an increased risk of infection [21] and an increased risk of some malignancies compared with the general population [22]. Evaluating safety, particularly infections, in older patients is complicated by the changes in the immune system that occur with increasing age [23]. Immunosenescence is known to affect older patients, and the presence of a chronic condition further increases the risk of infection in these patients [24]. In a retrospective study of patients with RA who were receiving anti-TNF therapy, discontinuation of treatment due to an $\mathrm{AE}$ was more common among patients $\geq 65$ years of age than in younger patients [25]. A higher incidence of serious infections has been seen in elderly patients with RA treated with anti-TNF agents (infliximab, adalimumab, etanercept) [26] and Janus kinase inhibitors (tofacitinib [27] or baracitnib [28]).

Among patients who were using concomitant corticosteroids at baseline, the incidence of serious infections was numerically higher for patients $\geq 65$ years than for patients $<65$ years. No apparent difference between age groups was observed for patients who were not receiving corticosteroids at baseline. This is consistent with an increased risk of infections, such as viral infections, tuberculosis, sepsis, and bacterial pneumonia, observed in patients receiving oral corticosteroids [29]. This offers a clear message to clinicians to strive to reduce and/or eliminate concomitant use of corticosteroids in elderly patients. This post hoc analysis is limited by the relatively small patient numbers in the older age groups. In addition, these results may have been confounded by the effect of immunosenescence in these patients.

\section{Conclusions}

The results from this exploratory analysis suggest that clinical efficacy of IV golimumab $2 \mathrm{mg} / \mathrm{kg}$ plus MTX is similar between patients $\geq 65$ years and those $<65$ years. We observed a slightly higher numeric incidence of serious infections for patients $\geq 65$ years, $\geq 70$ years, and $\geq 75$ years compared with the younger age groups. In general, the types of AEs observed in the older age groups were consistent with the known safety profile of golimumab. However, it should be noted that the results of this post hoc analysis are based on small patient numbers, particularly in the age groups $\geq 70$ years and $\geq 75$ years. Additionally, the increased risk of infection with age due to immunosenescence complicates the interpretation of these results in older patients. Although this analysis did not demonstrate a stronger signal for serious infections, these results do advise cautious patient selection for risk and monitoring for serious infection for older patients receiving golimumab. This is especially true with the use of concomitant corticosteroids, which in this study, was associated with a higher incidence of serious infections, consistent with findings from other studies that examined older age patients.

\section{Abbreviations \\ ACR: American College of Rheumatology; AE: Adverse event; \\ AS: Ankylosing spondylitis; DMARDs: Disease-modifying anti-rheumatic drugs; HAQ-DI: Health Assessment Questionnaire-Disability Index; \\ HRQoL: Health-related quality of life; IV: Intravenous; MTX: Methotrexate; NSAIDs: Nonsteroidal anti-inflammatory drugs; PsA: Psoriatic arthritis; RA: Rheumatoid arthritis; SAE: Serious adverse event; SC: Subcutaneous; SF-36 PCS/MCS: 36-item Short-Form Health Survey Physical and Mental Component Summary; TB: Tuberculosis; TNF: Tumor necrosis factor}

\section{Acknowledgements}

The authors thank Rebecca Clemente, PhD, of Janssen Scientific Affairs, LLC, for writing support.

\section{Authors' contributions}

JT contributed to the study design and data interpretation. SK contributed to the study design, data collection, and interpretation. RJD contributed to the study design and data interpretation. SX contributed to the study design and statistical analysis. ECH contributed to the data interpretation. AT contributed to the data interpretation. All authors revised the manuscript and gave final approval for submission.

Funding

This study was funded by Janssen Research \& Development, LLC.

\section{Availability of data and materials}

The data sharing policy of Janssen Pharmaceutical Companies of Johnson \& Johnson is available at https://www.janssen.com/clinical-trials/transparency. As noted on this site, requests for access to the study data can be submitted through Yale Open Data Access (YODA) Project site at http://yoda.yale.edu.

\section{Ethics approval and consent to participate}

The GO-FURTHER trial was conducted in accordance with Good Clinical Practice and the Declaration of Helsinki. The protocol was approved by the Institutional Review Board or ethics committee at each site. All patients gave written informed consent before any study-related procedures were performed.

\section{Consent for publication}

Not applicable.

\section{Competing interests}

JT has received consulting and speaker fees and research support from AbbVie, Amgen, Janssen, Lilly, and Pfizer. AT has received consulting and 
speaker fees and research support from AbbVie, Janssen, Lilly, Medac, Novartis, Pfizer, and Regeneron. SK, RJD, SX, and ECH are or were employees of Janssen Research \& Development, LLC. at the time this work was performed and own stock in Johnson \& Johnson, of which Janssen Research \& Development, LLC. is a wholly-owned subsidiary.

\section{Author details}

${ }^{1}$ Arizona Arthritis and Rheumatology Associates, Phoenix, AZ, USA. ${ }^{2}$ Janssen Scientific Affairs, LLC, Horsham, PA, USA. ${ }^{3}$ Sidney Kimmel School of Medicine, Thomas Jefferson University, Philadelphia, PA, USA. ${ }^{4}$ Janssen Research \& Development, LLC, Spring House, PA, USA. ${ }^{5}$ University of Pennsylvania, Philadelphia, PA, USA. ${ }^{6}$ Rheumatology Associates, Birmingham, AL, USA.

Received: 22 December 2018 Accepted: 25 July 2019

Published online: 20 August 2019

\section{References}

1. Emery P, Fleischmann RM, Strusberg I, Durez P, Nash P, Amante EJ, Churchill M, Park W, Pons-Estel B, Han C, et al. Efficacy and safety of subcutaneous golimumab in methotrexate-naive patients with rheumatoid arthritis: fiveyear results of a randomized clinical trial. Arthritis Care Res (Hoboken). 2016; 68(6):744-52.

2. Keystone EC, Genovese MC, Hall S, Bae SC, Han C, Gathany TA, Xu S, Zhou Y, Leu JH, Hsia EC. Safety and efficacy of subcutaneous golimumab in patients with active rheumatoid arthritis despite methotrexate therapy: final 5-year results of the GO-FORWARD trial. J Rheumatol. 2016:43(2):298-306.

3. Smolen JS, Kay J, Landewe RBM, Matteson EL, Gaylis N, Wollenhaupt J, Murphy FT, Zhou Y, Hsia EC, Doyle MK. Golimumab in patients with active rheumatoid arthritis who have previous experience with tumour necrosis factor inhibitors: results of a long-term extension of the randomised, double-blind, placebo-controlled GO-AFTER study through week 160. Ann Rheum Dis. 2012;71(10):1671-9.

4. Kavanaugh A, McInnes IB, Mease P, Krueger GG, Gladman D, van der Heijde D, Zhou Y, Lu J, Leu JH, Goldstein N, et al. Clinical efficacy, radiographic and safety findings through 5 years of subcutaneous golimumab treatment in patients with active psoriatic arthritis: results from a long-term extension of a randomised, placebo-controlled trial (the GO-REVEAL study). Ann Rheum Dis. 2014;73(9):1689-94.

5. Deodhar A, Braun J, Inman RD, van der Heijde D, Zhou Y, Xu S, Han C, Hsu B. Golimumab administered subcutaneously every 4 weeks in ankylosing spondylitis: 5-year results of the GO-RAISE study. Ann Rheum Dis. 2015;74(4):757-61.

6. Sandborn WJ, Feagan BG, Marano C, Zhang H, Strauss R, Johanns J, Adedokun OJ, Guzzo C, Colombel JF, Reinisch W, et al. Subcutaneous golimumab induces clinical response and remission in patients with moderate-to-severe ulcerative colitis. Gastroenterology. 2014;146(1):85-95 quiz e14-85.

7. Bingham CO 3rd, Mendelsohn AM, Kim L, Xu Z, Leu J, Han C, Lo KH, Westhovens R, Weinblatt ME, on behalf of the GO-FURTHER investigators. Maintenance of clinical and radiographic benefit with intravenous golimumab therapy in patients with active rheumatoid arthritis despite methotrexate therapy: Week-112 efficacy and safety results of the openlabel long-term extension of a phase III, double-blind, randomized, placebocontrolled trial. Arthritis Care Res (Hoboken). 2015;67(12):1627-36.

8. Kavanaugh A, Husni ME, Harrison DD, Kim L, Lo KH, Leu JH, Hsia EC. Safety and efficacy of intravenous golimumab in patients with active psoriatic arthritis: results through week twenty-four of the GO-VIBRANT study. Arthritis Rheumatol. 2017;69(11):2151-61.

9. Deodhar A, Reveille JD, Harrison DD, Kim L, Lo KH, Leu JH, Hsia EC. Safety and efficacy of golimumab administered intravenously in adults with ankylosing spondylitis: results through week 28 of the GO-ALIVE study. J Rheumatol. 2018:45(3):341-8.

10. Remicade: Package insert. Horsham: Janssen Biotech, Inc.; 2017.

11. Enbrel: Package insert. Thousand Oaks: Amgen; 2017.

12. Simponi: Package insert. Horsham: Janssen Biotech, Inc.; 2018

13. Simponi ARIA: Package insert. Horsham: Janssen Biotech, Inc:; 2018.

14. Humira: Package insert. Abbott Park: AbbVie Inc:; 2019.

15. Schneeweiss S, Setoguchi S, Weinblatt ME, Katz JN, Avorn J, Sax PE, Levin R, Solomon DH. Anti-tumor necrosis factor alpha therapy and the risk of serious bacterial infections in elderly patients with rheumatoid arthritis. Arthritis Rheum. 2007;56(6):1754-64.
16. Cho SK, Sung YK, Kim D, Won S, Choi CB, Kim TH, Jun JB, Yoo DH, Bae SC. Drug retention and safety of TNF inhibitors in elderly patients with rheumatoid arthritis. BMC Musculoskelet Disord. 2016;17:333.

17. Bathon JM, Fleischmann RM, Van der Heijde D, Tesser JR, Peloso PM, Chon Y, White B. Safety and efficacy of etanercept treatment in elderly subjects with rheumatoid arthritis. J Rheumatol. 2006;33(2):234-43.

18. Weinblatt ME, Bingham CO 3rd, Mendelsohn AM, Kim L, Mack M, Lu J, Baker $D$, Westhovens $R$. Intravenous golimumab is effective in patients with active rheumatoid arthritis despite methotrexate therapy with responses as early as week 2: results of the phase 3, randomised, multicentre, double-blind, placebo-controlled GO-FURTHER trial. Ann Rheum Dis. 2013;72(3):381-9.

19. Fries JF, Spitz P, Kraines RG, Holman HR. Measurement of patient outcome in arthritis. Arthritis Rheum. 1980;23(2):137-45.

20. Ware JE Jr, Sherbourne CD. The MOS 36-item short-form health survey (SF-36). Conceptual framework and item selection. Med Care. 1992;30(6): 473-83.

21. Ali T, Kaitha S, Mahmood S, Ftesi A, Stone J, Bronze MS. Clinical use of anti-TNF therapy and increased risk of infections. Drug Healthc Patient Saf. 2013;5:79-99.

22. Smitten AL, Simon TA, Hochberg MC, Suissa S. A meta-analysis of the incidence of malignancy in adult patients with rheumatoid arthritis. Arthritis Res Ther. 2008:10(2):R45.

23. Pawelec G. Immunosenescence: impact in the young as well as the old? Mech Ageing Dev. 1999;108(1):1-7.

24. Castle SC. Clinical relevance of age-related immune dysfunction. Clin Infect Dis. 2000:31(2):578-85.

25. Murota A, Kaneko Y, Yamaoka K, Takeuchi T. Safety of biologic agents in elderly patients with rheumatoid arthritis. J Rheumatol. 2016;43(11):1984-8.

26. Galloway JB, Hyrich KL, Mercer LK, Dixon WG, Fu B, Ustianowski AP, Watson KD, Lunt M, Symmons DP, Consortium BCC, et al. Anti-TNF therapy is associated with an increased risk of serious infections in patients with rheumatoid arthritis especially in the first 6 months of treatment: updated results from the British Society for Rheumatology Biologics Register with special emphasis on risks in the elderly. Rheumatology (Oxford). 2011;50(1):124-31.

27. Curtis JR, Schulze-Koops H, Takiya L, Mebus CA, Terry KK, Biswas P, Jones TV. Efficacy and safety of tofacitinib in older and younger patients with rheumatoid arthritis. Clin Exp Rheumatol. 2017;35(3):390-400.

28. Fleischmann R, Alam J, Arora V, Bradley J, Schlichting DE, Muram D, Smolen JS. Safety and efficacy of baricitinib in elderly patients with rheumatoid arthritis. RMD Open. 2017;3(2):e000546.

29. Brassard P, Bitton A, Suissa A, Sinyavskaya L, Patenaude V, Suissa S. Oral corticosteroids and the risk of serious infections in patients with elderlyonset inflammatory bowel diseases. Am J Gastroenterol. 2014;109(11):1795802 quiz 1803.

\section{Publisher's Note}

Springer Nature remains neutral with regard to jurisdictional claims in published maps and institutional affiliations.

Ready to submit your research? Choose BMC and benefit from:

- fast, convenient online submission

- thorough peer review by experienced researchers in your field

- rapid publication on acceptance

- support for research data, including large and complex data types

- gold Open Access which fosters wider collaboration and increased citations

- maximum visibility for your research: over $100 \mathrm{M}$ website views per year

At BMC, research is always in progress.

Learn more biomedcentral.com/submission 